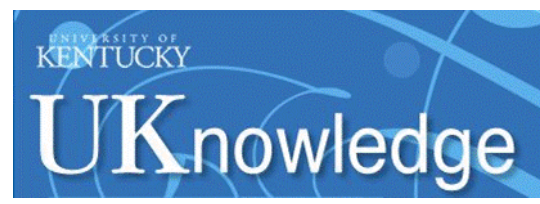

University of Kentucky

UKnowledge

\title{
Compulsory Homosexuality and Black Masculine Performance
}

Vershawn A. Young

University of Kentucky, vershawn.young@uky.edu

Follow this and additional works at: https://uknowledge.uky.edu/english_facpub

Part of the African American Studies Commons, English Language and Literature Commons, and the Performance Studies Commons

Right click to open a feedback form in a new tab to let us know how this document benefits you.

\section{Repository Citation}

Young, Vershawn A., "Compulsory Homosexuality and Black Masculine Performance" (2011). English Faculty Publications. 1.

https://uknowledge.uky.edu/english_facpub/1

This Article is brought to you for free and open access by the English at UKnowledge. It has been accepted for inclusion in English Faculty Publications by an authorized administrator of UKnowledge. For more information, please contact UKnowledge@lsv.uky.edu. 


\section{Compulsory Homosexuality and Black Masculine Performance}

\section{Digital Object Identifier (DOI)}

http://dx.doi.org/10.13008/2151-2957.1095

\section{Notes/Citation Information}

Published in Poroi, v. 7, no. 2, article 3.

The author may include the officially published version of the article (version of record) in an institutional or disciplinary repository, provided the posting includes a prominent statement of the full bibliographical details, and a link to the online edition of the journal. 


\section{Poroi}

An Interdisciplinary Journal of Rhetorical Analysis and Invention

ISSN 2151-2957

Volume 7

DOI: $10.13008 / 2151-2957.1095$

Issue 2 (2011)

Article 3

Sexing the Colorlines: Black Sexualities, Popular

Culture, and Cultural Production

\section{Compulsory Homosexuality and Black Masculine Performance}

Vershawn A. Young University of Kentucky

Copyright (C) 2011 Vershawn A. Young

\section{Recommended Citation}

Young, Vershawn A.. "Compulsory Homosexuality and Black Masculine Performance." Poroi 7, Iss. 2 (2011): Article 3.

Available at: http://dx.doi.org/10.13008/2151-2957.1095

Hosted by Iowa Research Online

This Article is brought to you for free and open access by Iowa Research Online. It has been accepted for inclusion in Poroi by an authorized

administrator of Iowa Research Online. For more information, please contact lib-ir@uiowa.edu. 
Sexing the Colorlines: Black Sexualities, Popular Culture, and Cultural Production

\section{Compulsory Homosexuality and Black Masculine Performance}

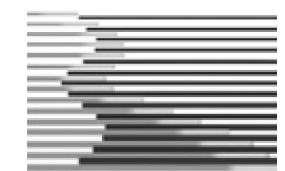

and

POROI

Vershawn Ashanti Young

Dept. of English, Rhetoric and African American Studies, University of Kentucky, Lexington, KY USA

Poroi 7, 2 (June 2011)

Young appears coy here about the status of his sexuality. He seems invested in rendering a story that highlights how he is constantly perceived as a "faggot" due to his failed performance of proper (black) masculinity and his ability to speak WEV. But he never explicitly claims a gay identity, leaving the reader to speculate.

\section{Press Reader 1 for Your Average Nigga}

Young is conversant with the ideas that Richard Rodriguez espouses in HUNGER OF MEMORY, and disagrees with many of them, yet fails to connect Rodriguez' arguments about language to Rodriguez' gender and sexual conflict, which become apparent in later works. [Rodriguez's] admiration for those brown male bodies sweating under hard labor in the sun was not simply--as we find out later--just a symbol of lost Mexican culture... Rodriguez is an interesting example for him in more ways than one.

Press Reader 2 for Your Average Nigga

I admit to admiring black men in the barbershops I frequent, describing them in the prelude of my first book, Your Average Nigga (2007), as speaking a "spicy black lingo" and performing the black masculinity I wish to embody yet fail to fully enact. In that book my main intent was to discuss gender performance and not sex/sexuality, risking for theoretical purposes a binary that scholars of queer studies and performance studies, such as Judith 
Butler $^{1}$ and E. Patrick Johnson (2001, 2003) have worked to deconstruct. I was, however, borrowing from a particular perspective on masculine performance that does draw a distinction between gender and sexuality, a distinction perhaps best articulated by writer James Baldwin. In a personal reminiscence on various identity labels, he says, "The condition that is now called gay [circa 1985) was then called queer [when he was coming of age]. The operative word was faggot and, later, pussy, but those epithets really had nothing to do with the question of sexual preference: You were being told simply that you had no balls" (emphasis in original, 1985, 681). Still, even with Baldwin's convincing anecdote, I am aware that the issues raised in the epigraphs by both prepublication readers are quite valid. In fact they prompt a question I had not previously entertained: Can I obtain through copulation the gender satisfaction I cannot achieve through imitation?

Similar questions regarding sexuality have been raised about black male autobiographers who ruminate on perceptions of their gender performance. Literary critic Kenneth Warren, for instance, says, "there is not enough of [Michael] Awkward," in his Scenes of Instruction (1999), "overcoming anxieties about his masculinity [and] his sexuality" (893). And even before encountering the passage where Awkward writes that his sister insists he disclose his sexuality ("Michael, are you a homosexual?"; "Michael, you sure you're not a faggot?" [61-61]) I had speculated about his orientation myself. He writes later in the book that he is heterosexual.

These examples highlight the guesswork and homoerotic innuendo that, I argue, is always raised by black male gender performance, particularly performances that are not explicitly or verifiably heteronormative. To put it another way, when black males' racial identity is called into question, as it inevitably is if we are or strive to be middle class, so is our sexuality; and while sexuality, according to some thinkers such as James Baldwin, is primarily a matter of private behavior, it is perceived to be performed publicly through gender, through one's display

${ }^{1}$ I am, of course, referring to Butler's well-known works on gender and sexuality, Gender Trouble (1990) and Bodies That Matter (1993). But my primary notation refers to perhaps a lesser-known interview with Butler where she flatly opposes gender/sex binaries. (See Peter Osborne and Lynne Segal, "Gender as Performance: An Interview with Judith Butler,” 1994). 
of masculinity. The problem is that the rules that govern adjudication of these performances shift in different contexts among different groups. So, the working-class, black masculine behaviors I covet in the barbershop that include jive talk, displays of swagger, and pimp walks, shift into performances that may be feared in a bank like Merrill Lynch. ${ }^{2}$ Thus an exceptional performance in one site is an unacceptable performance in another site. And what must the performer do when folks from two different sites, with different expectations, converge, when folks from Merrill Lynch mix with those from the barbershop? For which group must he perform? What is the measure of his success? What are the consequences of failure? How does he adequately represent his sexuality? And why must he have to?

In Your Average Nigga, I call the dilemma these questions pose the burden of black male racial performance, the burden to prove what constitutes your maleness and Blackness. I am stressing the relation between gender performance and sexuality here, and I want to place what I mean in that specific domain, and call the requirement for black men to front performative claims about their sexuality for speculative antagonists or curious friends, compulsory homosexuality. This term does not entail the pressure put upon someone to admit he is gay because he acts or speaks a certain way, nor does it mean outing someone you think you know is gay. Eve Kosofsky Sedgwick (1990) accomplished the aforementioned work

2 The reference to Merrill Lynch connects together to highly publicized cases of race involving Merrill Lynch. The first recalls the racial profiling of rap artist Juvenile (Terius Gray) in the summer of 2000. Juvenile was stopped by police officers along with his business associates in an upper class area of California at the ATM of a Merrill Lynch banking branch. According to reports, Juvenile and his associates were in California to tape an episode of a MTV summer series. The police questioned and detained him and his colleagues until their story checked out with their hotel and MTV (see Maria A. Lopez, The Criminal Element: Blacks In America.

http://clearinghouse.missouriwestern.edu/manuscripts/4 69.php).

The other is the 2005 racial discrimination suit filed by a group of African American brokers who work for Lynch (See http://registeredrep.com/news/merrill-racialdiscrimination/). 
in her seminal study on the epistemology of the closet. Instead, it defines the requirement all black males face to disprove or accept a homosexual identity as part of our performance of race.

For me, compulsory homosexuality is different from the way anti-gay, mostly ultra-religious conservatives use the term to describe their resistance to gay culture, literature, themes, and inclusive education. Ultraconservatives unfortunately view efforts to teach tolerance about people's sexualities as clandestine attempts to pressure vulnerable youth to be gay. However, my use of compulsory homosexuality signifies a distinct difference, which does not seek to reify a narrow-minded conservative viewpoint. In this context, I use the term to highlight the vexed relationship of race and sexuality to black male gender performance, a performance that must always respond to the question of homosexuality in relation to whiteness. Or, more generally, I argue that in relation to the mainstream, white masculinity defines black male gender performance within a patriarchal American culture. This terrain exists and is predominantly defined by and in relation to the social and political governance of white men.

Thus, in my use of the term black masculine performance, I am drawing on a range of scholars who argue that the relation of society to and its impact on gender/sexuality must always be taken into account. Among those are E. Patrick Johnson (2003) and Jose Estaban Munoz (1999). Since I want to be quite clear about my terms, let me briefly discuss points from the particular two sources -Baldwin and performance scholar Richard Schechner - that drive the way I am using performance. In his essay already quoted, Baldwin writes,

The American ideal, then of sexuality appears to be rooted specific in the American ideal of masculinity. This ideal has created cowboys and Indians, good guys and bad guys, punks and studs, tough guys and softies, butch and faggot, black and white $(1985,678)$.

Like Baldwin, I observe the enacting and the interrelationship of American society, gender, race and sexuality in the descriptors and epithets used to avow or ascribe gender performances. But what is a gender performance?

While discussing "construction of gender" as performance, Richard Schechner explains that, 
each individual from an early age learns to perform gender-specific vocal inflections, facial displays, gestures, walks, and erotic behavior as well as how to select, modify, and use scents, body shapes and adornments, clothing, and all other gender markings of a given society $(2002,151)$.

Schechner is not here assigning a limitless agency to gender-one that makes it only what one wishes it to be. But he is calling attention to gender's constructed nature, that we all learn gender through language and discourses that assign masculine and feminine values to cultural and personal behaviors. Following from this, we can potentially exploit what we learn in many instances to manipulate and habituate those behaviors that substantiate or subvert gender norms and expectations. At the same time, to be sure, gender is not a performance that is always endowed with agency for management. I think the following anecdote from Baldwin nicely illustrates gender as masculine performance, in the context in which I am using, and simultaneously calls out distinctions between gender and sexuality and their connectedness:

On every street corner, I was called a faggot. This meant that I was despised, and, however, horrible that is, it is clear. What was not so clear at that time of my life was what motivated the men and boys who mocked me and chased me; for, if they found me when they were alone, they spoke to me very differently-frightening me, I must say, into a stunned and speechless paralysis. For when we were alone, they spoke very gently and wanted me to take them home and make love (emphasis in original, 1985, 684).

Baldwin describes the masculine performance of the boys who called him "faggot" in terms of their varying vocal intonations and use of insults to front gender distinctions. Yet, some of Baldwin's apparently more masculine antagonists were interested in him sexually, which complicates easy correlations between gender performance and sex/sexuality. Heterosexual performances do not mean one is exclusively straight, nor do queer performances necessarily mean one is wholly gay. Baldwin came to understand this sexual complexity. Indeed, he recognized it from his own experience, but he still wondered what prompted these performances. That same wondering motivates part of the project of this essay. 


\section{The Difference Between White and Black Men}

The burden of racial performance and compulsory homosexuality are intertwined-inseparable-because sexuality, as I see it (pace James Baldwin), is a set of behaviors, a function of what we do and with whom we do it, rather than what we are-and so not really an identity at all. ${ }^{3}$ Race, on the other hand, is nothing but an identity, entirely a function of who we are rather than what we do. Notwithstanding, as I will discuss later, race has developed into a mixture of the two, an identity to which is added to the burden of an approved (or disapproved) behavior.

I further use the term compulsory homosexuality to describe this added burden instead of applying the critic and poet Adrienne Rich's (1980) provocative theorizing on "compulsory heterosexuality" because, first, her discussion is invested in the question of sexual orientation whereas my discussion is not. My primary interest is in the racialized gender performances used to assign a manly or unmanly status to black men, statuses that are taken as signs of sexuality. Second, Rich concerns herself with releasing the lesbian experience from the heterosexist pressure that causes its erasure from feminist discourse, a site where it should exist as most prominent. Rich exposes and objects to this pressure because it leads women to unwittingly support or, worse, ignore the heterosexism that seeks to place control of women's reproductive powers in the hands of men. In so doing, this process seeks to identify them as the proper body and sexual objects of male desire. This applies especially and directly to the relationship between white men and white women, and perhaps indirectly to black women, but not at all, or at least not in the same way, to black men.

The normative gender behavior and sexuality that black men respond to are not the same as the heteronormative sexuality held out for white men. As sociologist Roderick A. Ferguson (2004) puts it, "African American culture has historically been deemed contrary to

3 In an 1984 interview with Richard Goldstein, then editor of The Village Voice, Baldwin says: "It seems to me simply that a man is a man, a woman is a woman, and who they go to bed with is nobody's business but theirs. I suppose what I'm really saying is that one's sexual preference is a private matter" (183). (See James Baldwin: The Legacy, ed. Quincy Troupe. Simon and Schuster: New York, 1989.) 
the norms of heterosexuality and patriarchy" on the basis of race. Black men thus must always respond to considerations of their racial difference - "the sign of nonheteronormativity presumed to be fundamental to African American culture" $(20,21)$. That is to say, assigning nonheteronormative behavior to black men historically exists as a way to disenfranchise us from the opportunities reserved for white men in this country and thus from perceptions of "true" manhood, and from that "true" heterosexuality. A major consequence of this disenfranchisement is that it itself produces and perpetuates this nonheteronormativity, which one might better understand in this context as homonormativity.

Marlon Ross's brilliant study Manning the Race (2004) helps to illuminate black men's response to this homonormativity, by pointing out how for us the word man is a verb, a performance, an action, something to achieve. This is illustrated in the command I often heard as a boy -- "man up!" -- when I was acting in ways others perceive as unmanly. Of course, white boys, my white friends tell me, are also subject to such invectives. Nevertheless, the impact of race on blacks is different from the way it affects whites and this difference is most significant. When white men are told to "man up" or given some like command to perform gender, there is no stake in their racial identity. There is no perception that they are any less white if they do not "man up." In this sense, and in view of our historical situation, the insistence to man up for white men is understood as the effort to retain the heterosexuality one believes they have because they are white; for black men it is the effort against the homosexuality others may perceive us to have because we are not white.

This is not to say that black men are exempt from compulsory heterosexuality. To the contrary, we all are subject to the normative expectation of heterosexuality, where variation from that normative expression is deemed deviant, in need of correction, straightening out. What makes the situation different and worse for black men, however, is that we must navigate through zones of contradiction. Ross describes this dilemma that began during legal segregation as "an impossible paradox" - that while the logic of racial difference "insists on black men's natural deficiency as men, it necessarily demands that they adhere and aspire to the social codes established for the conduct of men" $(2004,2)$. In other words, there was a requirement for black men born into Jim Crow to be men on the basis of gender, yet there was a denial of male 
privilege because of their race. Although legislation made discrimination against color and heritage illegal, there was an entrenchment of the attachment of unjust stigmas and the codification of signifiers of blackness put upon black male bodies.

Therefore, while for both black and white men the primary task is performing acceptable manhood; for black men, the problem remains how to perform that manhood without abandoning their definition of Blackness. Of course, under Jim Crow they had no choice. The racial infrastructure required that they abandon the performance of manhood publically as to not threaten that structure. Those of us born into desegregation then face an impossible paradox of gender performance: If white men set the standard for mainstream, middle-class masculinity, then black men can try to downplay culturally black characteristics in order to be read as sufficiently male (in a white paradigm); but this puts them at risk at being read at insufficiently black, even though it's required by whites. At the same time, within their own culture, more often than not, if black men do not embrace expressions of blackness, especially those that define black masculinity, they risk being read as both insufficiently male and insufficiently black. As a result, one way to understand black hypermasculinity or exaggerated displays of manliness is as a response to the threat of losing their manhood in a society that privileges the whiteness of masculinity. One way in which to understand the concept of homonormativity in this context is to make black males' inability to meet the norms of manhood appear as typically a circumstance of homosexuals.

\section{Masculine Performance and Black Class Difference}

While I believe all black men face this problem, those from the underclass, who desire to increase their class status, are in a precarious position, one where there is a pronounced impact of compulsory homosexuality. Since working-class males exist within a context that is the extreme counter culture to middle-class whiteness, the site of so-called authentic blackness, leaving that site, as they must do to be acceptably middle class, appears as the effort to leave blackness. From this perspective, many feel as though they are leaving a valuable manhood among blacks behind and teetering toward unmanliness. Thus many view aspiring to the middle class as not a way out of a gender or 
racial problem, but as a further entrenchment into that problem.

Middle class males also experience this burden. They are the group that sociologist E. Franklin Frazier says develops "personalities"-gender identities they "have tended to cultivate" amidst whites in order to gain influence and power $(1957,220)$. Frazier's discussion of middle-class personalities includes a qualification about homosexuality. Frazier writes: "one cannot determine the extent to which homosexuality among [black] males is a result of not being able to play the "masculine role." Frazier confirms that the question of homosexuality is connected to black male gender performance, even if it is "impossible to determine that extent to which homosexuality" (257) is a phenomenon that arises from blacks men's societal position.

Anthropologist Signithia Fordham provides another perspective in her influential ethnography Blacked Out (1996) that helps parse how compulsory homosexuality differentially affects members of different classes or, as I shall use, class orientations in her study of black students at an inner city high school in Washington D.C. Fordham found that academically under-achieving, which I read in the context of school as working-class oriented, and highachieving, or middle-class oriented, black male students, affirm their black masculine identities through different performances that deny homosexuality. Fordham writes that, "the high-achieving males repeatedly took [her] to a well-known sex store...to assure [her] that they were real men" (27, italics mine). These same students also found it necessary for others to see them as "having a steady girlfriend." Even when the parents of one boy did not allow him to date "because of his age," he sought to verify his manhood by untruthfully telling Fordham that on a frequent basis he went to sex shops and that he and "one of his female classmates is 'an item'" (174). In contrast to the high-achieving males, "no underachieving male," Fordham writes, "indicated that going to the sex shop or pornography store was a typical part of his after-school routine" $(2008,348)$. Why in an all black high school did the middle-class oriented males appear to feel the burden to foreground a hyper heterosexual performance (e.g., going to sex shops) more than the working-class oriented males did? Fordham leaves this question open, and I do not have the inclination to answer this question here. Still, the question does direct attention to a point about the loss of racial identity and the middle-class oriented males' gender performance. The other point is that the middle- 
class males were undeniably responding to the compulsory homosexuality they feel as a result of having to act like what many may perceive as "white."

In a her recent essay, "Beyond Capital High," that Fordham writes as a follow up to her study and to clarify gross misappropriations of her "acting white" hypothesis, she resists the notion that acting white is a term blacks use to criticize and demoralize the achievements of their black brothers. Instead, she writes:

[A]cting White is a scripted, even racialized performance, the goal of which is-perhaps unconsciously-something approximating attempted identity theft, not in the colloquial sense of stealing someone's credit card or bank account information but, more critically, in exchange for what is conventionally identified as success, racially defined Black bodies are compelled to perform a White identity by mimicking the cultural, linguistic, and economic practices historically affiliated with the hegemonic rule of Euro-Americans (2008, 234).

According to Fordham, acting white is a racial requirement thrust upon all blacks who want to achieve mainstream success. There is an implicit requirement to remove or downplay black cultural and linguistic practices and take up ones with an association to whites in exchange for success. Thus, Fordham's middle-class oriented black males who have to give up the very characteristics that define black masculinity and manhood feel a compulsion to front a heterosexual performance. Fronting romantic relationships with girls as a rite of passage into black manhood and as a way of securing a masculine identity is also apparent in the case of the under-achieving males. These students, like the high-achieving males, Fordham writes, "are expected to sow wild oats in the process of becoming men" (176). Being linked to "a bevy of girls" (176) and garnering the reputation as a "playboy or ladies' man" is presented as "the[ir] quintessential evidence of manhood" (177). Fordham analyzes these students "approach to dating and mating" as a "practice game" that is preparing them for participation in a "patriarchal order" (177). Because black men are not seen as rightful heirs of and participants within this patriarchal order, they must struggle to prove they are men by fronting heterosexual relationships, even if they are gay, as recent discussions of 
the "down-low" illustrate, which is a vernacular term used to describe black men who hide that they have sex with other men, many of whom have public, romantic relationships with women. The down low, or the cover up of their homosexual practice, is an outcome of black males' marginalization within the patriarchal order, because in this order, black homosexuality appears as a confirmation of their inferior racial status.

In his review of Michael Awkward's memoir that I mentioned at the outset, Kenneth Warren concludes that Awkward's self-proclamation of black feminist efforts is "beside the point" in the midst of a feminist "politics more interested in creating a world where women can control their reproductive lives." In relation to the white patriarchal order in which black men function, one might ask a significant question: What would happen to the process of acquiring and performing a black masculine identity if women create a world where they could freely and without scorn, as Warren words it, "decide whether or not to have children with or without a male partner" (2000, 894)? Stated more directly, the question is, "How will black men perform heteronormative masculinity, to act like 'men' if women do not enter into sexual relationships with them?" This question has wide implications for the socialization of black men in mainstream and middle class environments.

Note another example of a high-achieving male in Fordham's study who further attempts to separate himself on the basis of sexuality from other middle-class oriented males. Martin was a student who embraced the term brainiac that his peers would often use to tease the smart kids. However, Martin felt the need to distinguish himself and other male brainiacs from the pervert brainiacs, who were male students Martin perceived as homosexual. Martin cites an example: "I be calling them ['pervert brainiacs'] gay, too. I be calling - I called this guy, Venny I said, 'Venny, man you be acting a little gay - gay a little bit, man, you better find a girl, man!' And say, 'You want a girl, man, I can hook you up" (2008).

It is clear from this example that Martin sees a romantic relationship with women as a way to signal a stable masculine identity. It is also a way for a male who some perceive as homosexual, a pervert brainiac, to efface that label. What is more, Martin holds himself up as a male who is highly influential with women - so influential that he can hook Venny up with a girl. In other words, he can 
get a girl to have a romantic relationship with a pervert braniac. Besides implying a certain amount of masculine charm to get the girl to do this, his comment suggests that he could easily choose a girl for Venny from among those in his harem, indicating a kind of male superiority to female sexual submissiveness. In any case, the black masculine identity must perform romantic domination over women; this is the challenge of being a middle class male that exists in opposition to the mainstream.

In this sense, when black men adopt the heterosexist practices that oppress others, Adrienne Rich's critique of compulsory heterosexuality applies. Indeed black men can impose compulsory heterosexuality on others, since, as Fordham makes clear, "In a patriarchal society like the United States, there is a 'patriarchal dividend' that accrues to Black males despite their racial subordination" (1994). My claim is that a primary motivation for accepting the "patriarchal dividend," for becoming willing subjects of compulsory heterosexuality and further imposing it on others, is to diminish and counter the burden of compulsory homosexuality.

\section{Gender Performance in Black Barbershops}

Since the black barbershop fosters linguistic engagement among a variety of black men and is a place where we share our goals and discuss our views, and since different types of black males frequent the site, it provides the perfect cultural context to examine some other responses to compulsory homosexuality among black men. Looking at responses in a predominantly or all black environs show that compulsory homosexuality is not a pressure that occurs only in the presence of whites or in sites coded as white, such as schools, or mainstream businesses. Instead, it arises from black men's position in society, which means that no matter the cultural locale, there are potential responses to it. Quincy Mills' ethnography of a barbershop on Chicago's South Side and the two recent popular movies-Barbershop I and Barbershop II: Back in Business, which are also set in Chicago and dramatize the type of the responses Mills writes about, are exemplary case studies.

In both Mills' study and in the Barbershop movies, the most contentious and problematic figure is a black male who is marginalized from the others on the basis of a perception that he lacks sufficient masculinity. Eric is the name of the man in Mills' study; Jimmy is the name of the character in the Barbershop movies. Mills describes Eric 
as "one of the regulars in the shop." Unlike other patrons, however, "his identity is shrouded in suspicion and innuendo" because "the barbers and many customers assume that Eric is gay." As a result, unlike other regulars who become key players in the discourse community, Mills writes that Eric "is silenced as an agenda setter." "When [he] would initiate conversations, the men would turn away, ignore him, or patronize him for a short while only to move quickly to other topics" (2006). Instead of engaging Eric, they would "act annoyed by his mannerisms and voice." Mills does not describe any particulars of his "voice" and "manner" but it is conclusive that for the others his masculine performance marks him as insufficiently heterosexual or, perhaps more importantly, as insufficiently anti-homosexual.

What is interesting about the other men's perception of Eric's sexuality is that it has no basis in fact; rather, the basis for his identity centers on how he acts. On this point Mills writes: "Eric never came out to me," he says, nor did he to the other men, since "there was no confirmation of his sexual identity in the months [Mills] spent at the shop." The question of Eric's sexuality seems to take on particular pertinence in the face of his education and class interests. We get a sense of this when Mills reports that he "talk[ed] with Eric one day about his education plans," suggesting that Eric is a young man, a college student, one with dreams of prosperity and leisure. In this regard Mills goes on to say that at least "once, during one of Eric's long narratives about places he'd seen and plans for his future travel, one of [the other men] whispered to [Mills], 'He's a little fruity" (2006). Eric's academic goals and his past and impending travels are indeed signifiers of his class aspirations. It is naïve to think that these are the only reasons for his estrangement, as the others had intents on being content with little and had resentment for Eric for wanting more in his life.

What the other black men are unfortunately reading in Eric's behavior and speech is a desire to give up his blackness and his masculinity in exchange for success. What they fail to realize, is that it is wrongheaded for them to view Eric as less black and masculine, and it is also wrongheaded to view their ignorance as a problem that begins or ends with them and to ignore how they are responding to the larger cultural terrain. The class difference is not only read as a sexual difference, but a racial one as well. This difference is made all the more clear in the films Barbershop I and Barbershop II, where Jimmy's (portrayed by Sean Patrick Thomas) 
representation is different from the other men, at odds with them; and not only with them, but with the one white male in the movie who "acts black" and the only black female barber. Jimmy's portrayal is that of an antagonizer, wielding his language habits and knowledge over the others, trying to subordinate them; but on more than one occasion, his nemesis, Ricky (portrayed by Michael Ealy), a ghetto boy and a three-time felon shows him up as wrong. In the movie, Ricky does not directly accuse him of being gay, but Jimmy's portrayal is outside of the realm of explicit heterosexuality. He is not given any kind of female love interest in either movie nor is he involved in any conversations that would indicate heterosexual interest. Within the first few minutes of the movie, the narrative represents all the other men as heterosexual through either discourse or behavior. I argue that the representation of black men throughout the film constitutes a response to compulsory homosexuality. For example, about ten minutes into the film a black male customer makes the claim during a discussion that a woman's "Ass is like money -- you can never have too much." He thus begins a discussion that solidifies the heterosexuality of all those who participate. All the black men in the shop perform heterosexual masculinity, except for one, Jimmy.

After the customer's statement, the barbershop proprietor and male lead in the movie Calvin (portrayed by Ice Cube) yells: "Yo', Rick. Yo'. School these boys on your philosophy about ass. You know, cuz' they can't distinguish between a woman with a big ass and a big ass woman."

Ricky obliges by extending a metaphor of rhetoric, philosophy, and mathematics, saying: "It's a ratio," that "If you measure around a woman's waist, and you measure 'round that ass; you come up with a ratio of about three five." Urged to give an example he cites a black woman of size, Mother Love, who the men appear to have sexual distaste for because she is a "big ass woman." They give the name "Jennifer Lopez" as one they would like to taste because she is a "woman with a big ass." Just as in Mills' ethnography where Eric is absent from sexual conversations that others use to front heterosexuality, so too is Jimmy conspicuously absent from the discussion. A camera shot shows him outside about to make a call on a cell phone. The only white barber, Isaac (portrayed by Troy Garity), arrives, and thus was also not a part of the conversation, but there is no exclusion of him from a heterosexual representation. He wears a Du-rag, jogging suit with big, silver and gold jewelry, which is reminiscent of rappers like Run DMC, and his black girlfriend drops 
him off while listening to rap music. He steps out of the car, grabs his black girlfriend's behind, and gives her a long, involved French kiss. There is a shot of her behind as she walks to the car and Isaac ogles her with attention to her anatomy. Jimmy looks on in disgust at the scene. What is interesting about this scene is that the white male barber establishes his heterosexuality and masculinity on the very terms of black masculine behavior that are arguably rendered unavailable to Jimmy as a middle-class oriented black man. This illustrates the extent to which white men can move through and appropriate various performances of racialized masculinity. There is a restriction of the performance of masculinity for black men and other men of color, which breeds detrimental consequences. Inside the shop, Jimmy and Isaac engage in their routine conflict about race:

Isaac: Man, don't hate on me just cuz you a sellout.

Jimmy: You got the black girlfriend, you got the pimped-out ride, and I'm a sell out? Man you ain't nothin' but a mistrel show turned on his ear. Al Jolson in a FuBu hat. Blackface for the new millennium.

Isaac: With all your higher education, why the only thing you talk about is me?

Jimmy: Cuz you don't belong here. The white barbershop is uptown.

Isaac: You know what I think...You wish you were me. You wish you had my fly ass girlfriend, and my pimped-out ride. Man, you even wish you had my clothes, my style, my walk. Why you think my fly ass girl ain't with you. Cuz yo' little bitch ass can't compete.

Jimmy: Well, I got news for you WHITEBOY, you're not black.

Isaac: Jimmy, I'm blacker than you, and what's messed up is that on your best day you could never be me.

Although the directorial intention of this scene is not to be ironic, for some spectators, at least for me, it is deeply ironic. Isaac's racial identity is never unstable or at risk. His coworkers simply accuse him of being out of play ("the white barbershop is uptown"). Jimmy never says, "You're not white enough." Nor could Jimmy respond to Isaac's statement "I'm blacker than you" with "So what, I'm whiter than you." No racial or gender benefit to that claim in that context exists for Jimmy, though there are benefits 
to Isaac's claim. And notice further how Isaac's construction of blackness is thoroughly working class and with a connection to heterosexuality that constitutes a "pimped out ride" and "fly ass girlfriend." He says that Jimmy desires to have his life, but Jimmy's failure is in Isaac's words, "cuz yo' little bitch ass can't compete." Thus, the white character effeminizes Jimmy because of lack of racial characteristics that should substantiate his masculinity. Indeed, Isaac's insult to Jimmy- “you could never be me" - is sad but true. As a middle-class oriented male, Jimmy could never be Isaac. Middle-class black men seeking influence among mainstream whites can be black enough to mark their race but must guard against being too black, lest face exclusion from the club of masculinity. If they seek influence among the black underclass or identification with them, like some rap artists, they have to guard against being too white.

\section{Conclusion}

I began this essay, by pointing out that both press readers for my book suggested that I write explicitly about my sexuality, not (I hope) for voyeuristic purposes, nor to pry into my sexual practice, but to enhance my theorizing about the relationship among class, masculinity and race. The first reader writes that I'm coy about my sexuality, leaving it unnamed, while the second reviewer not only speculates, but also insinuates that I am in sexual conflict. He compares me to Mexican-American author Richard Rodriguez and writes that Rodriguez is an interesting example for me "in more ways than one." It is the image of Rodriguez "admiring" "brown male bodies" that evidently makes him "an interesting example" for me, since it recalls my own admiration of black men. This reader suggests that these black men not only represent to me the cultural performance I long for, but are also a means for me to obtain it. The readers imply that I believe (but suppress) that the blackness I cannot achieve through racial performance can indeed be mine through homosexual performance. Indeed, it seems they read my loss and longing for a black masculinity as homonormative, as typical of the black homosexual. To accept this status, it is implied, would mean I might be able to reconcile and perhaps accept the black racial status with my own gender performance within the white masculine context from which my masculine loss and mourning arise. 
I do not highlight these readers' points to quibble with their queries or speculative insinuations. To the contrary, what I believe the readers may not see is why I left the question of sexuality open. I wanted to render obvious some of the societal circumstances that lead not only to the masculine performances of the so-called "faggot," ones like Eric and Jimmy, and the so-called niggas, like Ricky, Calvin and the barbers in Mills's study, but to a slew of what Frazier calls "personalities" that often go under theorized. The factors that beget these performances and thus the personalities themselves are distributed across class lines. Personalities found among middle class males are unlikely found in the exact same formation among the underclass.

Thus my "coyness" about my sexuality is performative. That is to say, my book performs, that is becomes, the gender problem I discuss, since not naming my sexuality, prompts the readers to speculate. They are performing the very phenomenon I describe in the book and here. Your Average Nigga and this essay are for me not only responses to compulsory homosexuality; it is also a challenge to it. For not claiming an explicit sexuality makes the dilemma more evident. Some may take this to mean I am a gay person and ask: Why would a straight person not name his sexuality? What negative consequences does he have to avoid? Or, some may read my efforts as that of a straight man attempting to engage the work of an empathetic ally. But really, as I see it, both readings are manifestations of compulsory homosexuality. My attempt, to be very clear, is to pinpoint the inherent flaws in the masculine performances discussed, inauthenticating them all, and making the task to identify and illustrate them and the question asked, not whether he is straight or gay, but (pace James Baldwin), "What compels various performances of masculinity and masculine conflict and why?"

\section{References}

Awkward, Michael. Scenes of Instruction: A Memoir. Duke: Durham, 1999.

Baldwin, James. "Here Be Dragons." The Price of the Ticket: James Baldwin Collected Nonfiction, 19481985. St Martin Press: New York, 1985.

Barbershop. Directed by Tim Story. 2002. MGM. DVD. 
Barbershop 2: Back in Business. Directed by Kevin Rodney Sullivan. 2004. MGM. DVD.

Ferguson, Roderick, A. Aberrations In Black: Toward A Queer Of Color Critique. University of Minnesota: Minneapolis, 2003.

Fordham, Signithia. "Beyond Capital High: On Dual Citizenship and the Strange Career of 'Acting White."” Anthropology \& Education Quarterly. Vol 39: no 3 (Sept 2008). 227-246.

--- Black Out: Dilemmas of Race, Identity, and Success at Capital High. The University of Chicago Press: Chicago, 1996.

Frazier, E. Franklin. Black Bourgeoisie. 1957. Free Press: New York, 1997.

Johnson, E. Patrick. Appropriating Blackness: Performance and the Politics of Authenticity. Duke University Press: Durham, 2003.

---““Quare' Studies, or, (Almost) Everything I Know about Queer Studies I Learned from My Grandmother." Text and Performance Quarterly. Vol 21: no 1 (2001). 1-25.

Mills, Quincy. "Truth and Soul: Black Talk in the Barbershop” Ed. Harris-Lacewell. Barbershops, Bibles and BET: Everyday Talk and Black Political Thought. Princeton University Press: Princeton, 2006.

Munoz, Jose Esteban. Disidentifications: Queers of Color and the Performance of Politics. University of Minnesota Press: Minneapolis, 1999.

Osborne, Peter and Lynne Segal. "Gender as Performance: An Interview with Judith Butler.” Eds. Stephen Olbrys Gencarella and Phaedra C. Pezzullo. Readings on Rhetoric and Performance. Stata Publishing Inc: State College, 2010.

Rich, Adrienne. "Compulsory Heterosexuality and the Lesbian Existence." Blood, Bread, and Poetry. Norton Paperback: New York, 1994.

Ross, Marlon. Manning the Race: Reforming Black Men in the Jim Crow Era. New York University Press: New York, 2004.

Schechner, Richard. Performance Studies: An Introduction. Second Edition. Routledge: New York, 2002.

Sedgwick, Eve Kosofsky. Epistemology of the Closet. 
Berkeley: University of California Press, 1991.

Warren, Kenneth. "Scenes of Instruction: A Memoir." American Literature. Vol 72: no 4 (Dec 2000). 893894.

Young, Vershawn Ashanti. Your Average Nigga:

Performing Race, Literacy, and Masculinity. Wayne State University Press: Detroit, 2007. 